http://dx.doi.org/10.1590/1678-4162-9115

Arq. Bras. Med. Vet. Zootec., v.69, n.5, p.1073-1082, 2017

\title{
Virulence, resistance, and genetic relatedness of Escherichia coli and Klebsiella sp. isolated from mule foals
}

\author{
[Virulência, resistência e relação genética de Escherichia coli e Klebsiella sp. \\ isoladas de potros de muar] \\ V.C. Carneiro ${ }^{1}$, D.A.B. Lessa ${ }^{1}$, P.M. Guttmann ${ }^{1,4}$, H. Magalhaes ${ }^{2}$, M.H.C. Aquino ${ }^{1}$, \\ L.E.R. Cunha ${ }^{3}$, L.R. Arais ${ }^{1}$, A.M.F. Cerqueira ${ }^{1 *}$ \\ ${ }^{1}$ Universidade Federal Fluminense - Niterói, RJ \\ ${ }^{2}$ PESAGRO - Niterói, RJ \\ ${ }^{3}$ Instituto Vital Brazil - Niterói, RJ \\ ${ }^{4}$ Centro Universitário Serra dos Órgãos - Teresópolis, RJ
}

\begin{abstract}
Respiratory diseases are common in young horses but little is known about such infections in mule foals. This study aimed to characterize Escherichia coli and Klebsiella sp. isolated from tracheal wash (TW) and fecal samples (FS) of mule foals, with or without cytological evidence of respiratory disease. Strains were analyzed against 13 antimicrobials, for presence of Extended spectrum beta-lactamase (ESBL), and virulence genes. Phylogrouping and Randomic (RAPD)-PCR profiles were used to evaluate their genetic relatedness. E. coli strains from TW and FS showed greatest resistance to tetracycline, while Klebsiella strains were mainly resistant to ampicillin; multidrug resistance and ESBL production were also detected. The blaCTX gene prevailed among the E. coli isolates, while the blaSHV gene was more frequently found in $K$. pneumoniae. The fim $H$ gene was detected in most of the isolates and multiple virulence factors were identified in three E. coli isolates. Most of the E. coli isolates belonged to the B1 phylogroup, but B2 strains displayed more virulence genes. The RAPD assay revealed genetic diversity among strains and was able to distinguish FS isolates from TW isolates. Knowledge of the bacteria associated with the respiratory tract of mule foals is important in the treatment of sick animals.
\end{abstract}

Keywords: Escherichia coli, Klebsiella, respiratory disease, virulence, antimicrobial resistance

\section{RESUMO}

Doenças respiratórias são comuns em potros de equinos, porém pouco se sabe sobre tais infecções em potros de muar. Este estudo buscou caracterizar Escherichia coli $e$ Klebsiella sp. isolados de lavados traqueais (TW) e amostras fecais (FS) de potros de muar com e sem evidências citológicas de doença respiratória. As amostras bacterianas foram testadas contra 13 antimicrobianos, para a presença de genes de resistência estendida às betalactamases (ESBL) e de virulência. Filogrupagem e perfis de PCR randômicos (RAPD) foram usados para avaliar sua relação genética. As amostras de E. coli de TW e FS mostraram maior resistência à tetraciclina, enquanto as amostras de Klebsiella foram mais resistentes à ampicilina; multirresistência e produção de ESBL também foram detectadas. O gene blaCTX foi mais frequente entre E. coli, enquanto o gene blaSHV foi mais encontrado entre K. pneumoniae. $O$ gene fimH foi detectado na maioria dos isolados de $\mathrm{E}$. coli, enquanto múltiplos genes de virulência foram identificados em três isolados de E. coli. A maioria dos isolados de E. coli pertenceu ao filogrupo B1, porém somente isolados do filogrupo B2 apresentaram mais genes de virulência. Os ensaios de RAPD demonstraram a diversidade genética entre as amostras e distinguiram amostras TW e FS. $O$ conhecimento de bactérias associadas a infecções de trato respiratório de potros de muar é importante no tratamento de animais doentes.

Palavras-chave: Escherichia coli, Klebsiella, doença respiratória, virulência, resistência antimicrobiana

Recebido em 9 dezembro de 2016

Aceito em 19 de janeiro de 2017

*Autor para correspondência (corresponding author)

E-mail: aloysiocerqueira@id.uff.br 


\section{INTRODUCTION}

Respiratory disorders are common in young horses, especially in foals between one to six months of age, and are caused by different infectious agents (Cohen, 1994; Ribas et al., 2009). Foals are more susceptible to infection after six weeks of birth when there is a decrease in passive immunity. Identification of the infectious etiologic agent enhances the effectiveness of the treatment and facilitates control of these diseases (Mellor and Stafford, 2004).

Most respiratory infections are caused by opportunistic bacterial pathogens, can be polymicrobial, and usually follow a previous viral respiratory illness, stress or parasitic infection due to host immunosuppression (Léguillette et al., 2002). The search and characterization of the resistance profile and virulence properties of microorganisms involved in such infections is of great importance for a better and more efficient therapeutic approach.

Enterobacteriaceae are bacterial agents usually present as transient microbiota in the respiratory tract. Escherichia coli and Klebsiella spp. are common causes of respiratory diseases in equine foals, and their virulence and antimicrobial resistance have been previously studied. (Champs et al., 2004; Deb Roy et al., 2008; El Fertas-Aissani et al., 2013; Theelen et al., 2014). Adhesins and toxins usually described in extraintestinal pathogenic strains and resistance to several antimicrobials like that associated with ESBL expression are of special interest. However, there is a lack of information on respiratory diseases in mule foals and on the Enterobacteriaceae isolated during such infections.

Concerns about health conditions of mules have increased as these animals are important to the rural economy of developing countries and also as companion animals in Europe and the USA. Given their greater resilience, it is also possible for mules to replace horses in the production of immunoglobulin and hyperimmune sera.

Importantly, since donkeys are stoic and clinical signs of respiratory disease can be inconsistent and difficult to interpret, sick animals often present with advanced respiratory disease
(Thiemann, 2012). Thus, this study aimed to characterize the Escherichia coli and Klebsiella sp. strains isolated from tracheal wash (TW) and fecal samples (FS) obtained from mule foals of less than six months of age, with or without cytological evidence of respiratory infectious disease, and to establish their antimicrobial resistance profile, extraintestinal virulence markers and the genetic relatedness of these isolates.

\section{MATERIAL AND METHODS}

All the procedures performed during this study were approved by the Ethics Committee for Animal use, Fluminense Federal University (Protocol 0125/11).

Both TW and FS samples were obtained from 56 mule foals (total 112 samples) less than six months of age between December 2011 and November 2012 from a farm located at Cachoeiras de Macacu City, Brazil (22 ${ }^{\circ} 31^{\prime} 1.43^{\prime \prime}$ $\mathrm{S} / 42^{\circ} 41^{\prime}$ 52.18" W). TW samples were aseptically collected by endoscopy, and FS samples were collected using rectal swabs. TW cytology was used to classify the foals as healthy $(\mathrm{H})$ or sick (S), and samples were defined as 'sick' if they demonstrated numerous neutrophils, cellular degeneration and intra- and extracellular bacterial organisms, all of which are indicative of respiratory disease (Pusterla et al., 2006).

An amount of $1 \mathrm{~mL}$ of TW was immediately inoculated into $10 \mathrm{~mL}$ of Brain Heart Infusion (Himedia Labs., Mumbai, India) broth and incubated at $37{ }^{\circ} \mathrm{C}$ for $24 \mathrm{~h}$. The resulting growth was streaked onto MacConkey (Himedia) and Blood Agar (Himedia) plates. Suspected enterobacterial colonies were identified using the Enterokit B (Probac do Brasil, São Paulo, Brazil) according to manufacturer's instructions. Additional tests for Klebsiella species-level confirmation including Methyl Red, Voges Proskauer, Arginine dehidrolase and Ornitine decarboxilase tests were done as previously described (Markey et al., 2013). Identical methods were used for the isolation and identification of enterobacteria from FS.

The disk diffusion assay was used to determine antimicrobial susceptibility patterns and was performed according to Clinical and Laboratory 
Standards Institute (CLSI) recommendations (CLSI..., 2008; CLSI..., 2012). The antimicrobials used in these assays (CEFAR, São Paulo, Brazil) were selected based on routine use in Equine Medicine; and the following drugs or drug combinations were tested: amikacin, amoxicillin + clavulanic acid, ampicillin, ceftiofur, cefotaxime, ciprofloxacin, doxycycline, enrofloxacin, gentamicin, norfloxacin, streptomycin, sulfamethoxazole + trimethoprim and tetracycline. The isolates were then classified as either susceptible or resistant (including intermediate pattern).

Extended spectrum $\beta$-lactamase (ESBL) production was phenotypically detected in isolates that were resistant to beta-lactam antibiotics using the screening test and the results were based on established breakpoints for inhibition zone diameter (CLSI..., 2012). The ESBL-producing isolates were additionally screened for the presence of the blaCTX-M, blaTEM, and blaSHV genes by polymerase chain reaction (PCR) as previously described (Wiegand et al., 2007).

The presence of genetic virulence markers in extraintestinal pathogenic Escherichia coli (ExPEC) and Klebsiella pneumoniae, including afal, fimH, pap, kpsMTII, cnfl, and hlyA genes was analyzed by PCR (Johnson et al., 2000; Usein et al., 2001).

The phylogenetic grouping of E. coli isolates was performed based on established criteria (Clermont et al., 2000). The genetic relatedness of $E$. coli and $K$. pneumoniae isolates was evaluated through the Random Amplified Polymorphic DNA (RAPD) assay (Pacheco et al., 1997). Briefly, PCR reactions using the arbitrary primer 1254 were done. The PCR profiles observed after gel electrophoresis were transformed in a distance matrix generated by the RAPDistance 1.04 software (Armstrong et al., 1994) and were used to construct a dendrogram using the MEGA4 software (Tamura et al., 2007), which employed the UPGMA (Unweighted Pair Group Method with Arithmetic Mean) method for computation. A similarity index greater than $75 \%$ was used to define a RAPD type.
The association between antimicrobial resistance profile, extraintestinal virulence markers and genetic relationship in TW and fecal samples of both healthy and sick mule foals was evaluated using Qui Square Test or Fisher's Exact Test when applicable, assuming significance at a $\mathrm{p}$ value $<0.05$.

\section{RESULTS AND DISCUSSION}

Of the 56 foals tested, 27 were found to be sick (S) and 29 were healthy $(\mathrm{H})$. One hundred and forty isolates were recovered from TW samples and were predominantly enterobacteria $(n=73$, $46.8 \%)$; mainly E. coli $(\mathrm{n}=25,16 \%)$ and Klebsiella sp. $(\mathrm{n}=22,14.1 \%)$. One Klebsiella isolate was identified as $K$. oxytoca, while the remaining isolates were all $K$. pneumoniae. Citrobacter sp., Enterobacter sp., Proteus sp. and Serratia sp. were also less frequently isolated. All fecal samples contained Enterobacteria, but only those isolates recovered from the same animal of TW isolates $(20 \mathrm{E}$. coli and $2 K$. pneumoniae) were used for further analyses.

The prevalence of E. coli and Klebsiella sp. in TW samples was similar in both $\mathrm{S}$ animals (24 isolates) and $\mathrm{H}$ animals (23 isolates). Although the $E$. coli had a prevalence rate of $51.8 \%$ (14 out of 27) in sick animals and $37 \%$ (11 out of 29) in healthy animals, this difference was not significant $(\mathrm{p}=0.43)$.

Respiratory disease, a major problem in foals and adult horses, is generally associated with high morbidity and mortality, and can be caused by many different agents. Enterobacteria are frequently present in these infections; and the occurrence of E. coli and Klebsiella sp. has also been previously reported (Clark et al., 2008; Ryu et al., 2011). Further, E. coli is also prevalent in sepsis of neonatal foals (Russell et al., 2008). Presently, despite mules being as important as horses, similar studies on mules are scarce and the available data are minimal at best (Thiemann, 2012).

Increased antimicrobial resistance is a challenge in relation to the treatment of infectious diseases in animals. The choice of antimicrobials to be tested in this study was based on CLSI criteria and on a survey conducted among six local veterinarians responsible for 29 farms in the 
same region. According to this survey, antimicrobials most commonly used in treatment of equine foals, in order of importance, were penicillin and gentamycin $(>80 \%)$; ceftiofur and sulphametoxazol (67\%); azithromycin, rifampin and ceftriaxone (34\%); and, finally, amikacin, streptomycin and enrofloxacin (17\%) (unpublished data). Nonetheless, penicillin, azithromycin and rifampin were not tested in this study due to the natural resistance of Gram negative bacteria. All E. coli and Klebsiella isolates tested in this study showed no resistance to amikacin, ceftiofur, cefotaxime, ciprofloxacin or gentamycin.

Table 1 shows the resistance pattern of the $E$. coli and Klebsiella sp. isolates. Thirty TW isolates (64\%) and nine FS isolates (41\%) were resistant to at least one drug, and resistance against one or two drugs was the most commonly observed phenotype among these strains. E. coli strains from TW and FS showed greatest resistance to tetracycline at $20 \%$ and $30 \%$, respectively, while Klebsiella strains were most resistant to ampicillin at $77.3 \%$ and $50 \%$ for TW and FS isolates, respectively. While all FS E. coli isolates were susceptible to trimethoprimsulfamethoxazole, TW E. coli isolates showed $16 \%$ resistance. Similar resistance profiles were also found a in $E$. coli of fecal origin from young (Schoster et al., 2012) and adult (Maddox et al., 2012) healthy horses and may reflect the prevalence of circulating strains previously selected by the use of such drugs.

Table 1. Resistance profile of E. coli and Klebsiella sp. isolates recovered from tracheal wash and feces of mule foals

\begin{tabular}{lcccc} 
& \multicolumn{2}{c}{ E. coli $(\%)^{\mathrm{a}}$} & \multicolumn{2}{c}{ Klebsiella sp. $(\%)^{\mathrm{a}}$} \\
\cline { 2 - 5 } Antimicrobial* & $\begin{array}{c}\text { Tracheal Wash } \\
(\mathrm{n}=25)\end{array}$ & $\begin{array}{c}\text { Fecal } \\
(\mathrm{n}=20)\end{array}$ & $\begin{array}{c}\text { Tracheal Wash } \\
(\mathrm{n}=22)\end{array}$ & $\begin{array}{c}\text { Fecal } \\
(\mathrm{n}=2)\end{array}$ \\
\hline Ampicillin & 16 & 10 & 77 & 50 \\
Amoxicillin/ & 12 & 15 & 32 & 0 \\
Clavulanic Acid & 12 & 20 & 0 & 0 \\
Doxycycline & 20 & 30 & 14 & 0 \\
Tetracycline & 4 & 25 & 5 & 0 \\
Streptomycin & 4 & 0 & 0 & 0 \\
Enrofloxacin & 4 & 0 & 0 & 0 \\
Norfloxacin & 16 & 0 & 5 & 0 \\
Sulfametaxazol & & & & \\
/Trimethoprim & & &
\end{tabular}

The prevalence of resistant isolates was higher in $\mathrm{H}$ animals compared to $\mathrm{S}$ animals $(55.1 \%$ and. $37.0 \%$, respectively, $\mathrm{P}=0.27$ ), but when resistance in $E$. coli isolates alone was considered, the prevalence of resistant isolates was higher in $\mathrm{S}$ animals compared to $\mathrm{H}$ animals $(25.9 \%$ and. $10.3 \%$, respectively, $\mathrm{P}=0.12)$. Although a higher resistance rate could be expected from strains isolated from sick animals, resistance and virulence are not always associated. Moreover, from a clinical point of view, treatment of sick animals is easier when drug resistance is lower. However, it is important to note that these differences were not statistically significant.
Multiresistant isolates (resistant to at least one agent in three or more antimicrobial categories) were recovered with similar frequencies from both $\mathrm{S}(\mathrm{n}=2)$ and $\mathrm{H}(\mathrm{n}=1)$ animals. Multidrug resistance was detected in two (8\%) E. coli and one $(4.5 \%)$ Klebsiella sp. isolate from TW samples and in one $(4.5 \%)$ E. coli isolate from FS. Schoster et al. (2012) found $2.6 \%$ multidrugresistant $E$. coli fecal strains isolated from horses. However, even though Clark et al. (2008) also recovered $E$. coli strains from the respiratory tract of horses, they did not detect multidrug resistance in these isolates.

Fourteen isolates ( $\mathrm{n}=7$ for both TW and FS) were potential ESBL-producers. ESBL genes were identified in $6 \mathrm{TW}$ and $6 \mathrm{FS}$ isolates of which 4 
ESBL-producing isolates were from the TW of $\mathrm{H}$ animals. Similar to the comparison of resistance between $\mathrm{H}$ and $\mathrm{S}$ animals, differences were not significant. However, the presence of these strains from different origins (TW and FS) and conditions reinforces their circulation among the animals and the possibility of horizontal transfer of this feature to other microoganisms (Szmolka and Nagy, 2013.).

The blaCTX gene was most prevalent among $E$. coli, while the blaSHV gene was more frequently found in $K$. pneumoniae. The presence of both the blaTEM and the blaSHV genes was detected in one multidrug resistant $E$. coli isolate from one $\mathrm{S}$ animal and in two $\mathrm{K}$. pneumoniae isolates (one each from an $\mathrm{S}$ and an $\mathrm{H}$ animal). All except one of the FS isolates were E. coli, and they predominantly demonstrated the presence of the blaCTX gene (80\%). The blaCTX-M gene is becoming increasingly frequent among $E$. coli and Klebsiella pneumoniae (Jones et al., 2009; Dolejska et al., 2011).

All the virulence markers tested were detected in TW isolates, but at different frequencies. The fim $H$ gene that encodes type 1 fimbriae was the most frequently detected marker, both in the $E$. coli (92\%) and in the Klebsiella sp. (59\%) isolates (Figure 1). The Type I fimbriae, although common in intestinal commensal $E$. coli, are known adhesins in extraintestinal samples.

Two E. coli isolates from TW samples exhibited five of the six virulence genes investigated (Table 2). The TW17E isolate (from an S animal) displayed the fimH, kps, pap, hlyA, and cnf genes, while the TW29E isolate (from an $\mathrm{H}$ animal) exhibited the afa, fimH, kps, pap, and cnf genes. Furthermore, one isolate recovered from the FS of the same animal (FS29E), displayed the fim $H$, kps, hlyA, and cnf genes.

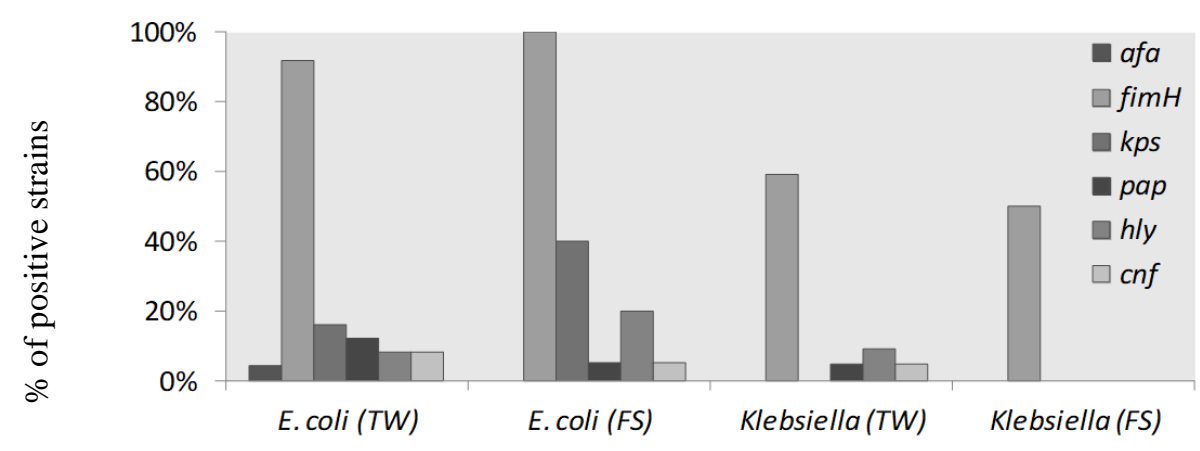

Figure 1. Extraintestinal virulence markers in E. coli and Klebsiella sp. isolated from mule foals (TW-tracheal washes; FS- fecal samples).

DebRoy et al., (2008) detected the presence of the cnf, fim $\mathrm{H}$ and pap genes in an E. coli strain isolated from a fatal case of bronchopneumonia in a mare. Other studies have shown that the pap, $a f a$, cnfl and kps genes are mainly found in uropathogenic and fecal isolates of animal and human origin (Maynard et al., 2004). The recovery of extraintestinal $E$. coli isolates from animals with virulence profile similar to strains of human origin points to the potential role of animals as reservoirs of these strains, or to the possibility of sharing these strains (Bélanger $e t$ al., 2011).

In $E$. coli strains from FS, the fimH virulence gene was present in all isolates, and all other virulence genes were detected, except the afa gene. These results are as expected, as it is known that the habitat of the extraintestinal pathogenic strains is the intestinal tract (Maynard et al., 2004). 
Table 2. Phenotypic and genotypic profile of $E$. coli isolates recovered from tracheal washes of mule foals

\begin{tabular}{|c|c|c|c|c|c|c|c|c|c|c|c|c|}
\hline \multirow[t]{2}{*}{ Isolate } & \multirow[t]{2}{*}{$\begin{array}{c}\text { Animal } \\
\text { condition* }\end{array}$} & \multirow[t]{2}{*}{ Resistance profile } & \multicolumn{3}{|c|}{ ESBL gene } & \multicolumn{6}{|c|}{ Virulence gene } & \multirow[t]{2}{*}{ Phylogroup } \\
\hline & & & $\begin{array}{c}\text { bla } \\
\text { CTX-M }\end{array}$ & $\begin{array}{c}\text { bla } \\
\text { TEM }\end{array}$ & $\begin{array}{l}\text { bla } \\
\text { SHV }\end{array}$ & afa & fim $\mathrm{H}$ & kps & pap & hlyA & cnf & \\
\hline TW11E & $\mathrm{H}$ & & & & & & + & & & & & $\mathrm{D}$ \\
\hline TW13E & S & & & & & & + & & & & & B1 \\
\hline TW15E & H & & & & & & + & & & & & B1 \\
\hline TW17E & S & & & & & & + & + & + & + & + & B2 \\
\hline TW23E & $\mathrm{H}$ & & & & & & & & & & & B1 \\
\hline TW24E & S & & & & & & + & & & & & A \\
\hline TW28E & H & & & & & & + & & & & & B1 \\
\hline TW29E & H & & & & & + & + & + & + & & + & B1 \\
\hline TW34E & S & AMC, AMP & & & & & + & & & & & A \\
\hline TW43E & S & AMC, AMP & & & & & + & & & & & A \\
\hline TW45E & S & & & & & & + & & & & & B1 \\
\hline TW46E & $\mathrm{H}$ & ENR & & & & & + & & & & & A \\
\hline TW47E & $\mathrm{H}$ & & & & & & + & + & & & & B1 \\
\hline TW48E & $\mathrm{H}$ & AMP & & & & & + & & & & & $\mathrm{D}$ \\
\hline TW49E & S & & & & & & + & + & & + & & B1 \\
\hline TW50E & S & & & & & & + & & & & & B1 \\
\hline TW52E & S & $\begin{array}{c}\text { SUT, TET } \\
\text { AMC, AMP, EST, }\end{array}$ & & & & & + & & & & & A \\
\hline TW53E & S & SUT, TET & & + & + & & + & & & & & B1 \\
\hline TW56E & S & DOX & & & & & + & & & & & $\mathrm{A}$ \\
\hline TW57E & S & DOX, SUT, TET & & & & & + & & & & & A \\
\hline TW58E & S & & & & & & + & & + & & & B1 \\
\hline TW14E & S & & & & & & & & & & & $\mathrm{D}$ \\
\hline TW32E & S & DOX, TET & & & & & & & & & & A \\
\hline TW33E & $\mathrm{H}$ & & & & & & + & & & & & B1 \\
\hline
\end{tabular}

* H, healthy; $\mathrm{S}$, sick: based on cytological criteria for respiratory disease

AMC - amxicillin+ clavulanic acid; AMP- ampicilin; DOX- doxycycline; ENR- enrofloxacin; EST - streptomycin; NOR - norfloxacin; SUT - sulphametoxazole+ trimethoprim; TET - tetracycline.

The genes pap, hlyA and cnf were detected only at low frequencies in Klebsiella strains from TW samples $(4.5 \%, 9.1 \%$, and $4.5 \%$, respectively), and none of the other genes studied, except fim $\mathrm{H}$, were detected in fecal isolates. There is little data about the presence of these virulence factors in Klebsiella sp., and these also only report the general presence of the fim $\mathrm{H}$ gene and the absence of the other genes investigated in this study (El Fertas-Aissani et al., 2013).

Despite a similar pattern of occurrence of virulence genes in both E. coli and Klebsiella isolates from both $\mathrm{S}$ and $\mathrm{H}$ animals, their role as causative agents of respiratory diseases cannot be ruled out. Other factors, including association with other microbial agents and previous viral respiratory infections, stress or parasitic infection due to immunosuppression of the host, also need to be considered (Cohen, 1994; Leguillette et al., 2002).
ExPEC strains usually belong to the B2 or the D phylogroups, while the enteropathogenic strains belong to the $\mathrm{A}, \mathrm{B} 1$ or $\mathrm{D}$ groups, and the commensal strains to the A or B1 phylogroups. Moreover, ExPEC strains with similar virulence profiles are usually from the same phylogroup (Johnson et al., 2002). In our study, both TW and FS E. coli isolates predominantly belonged to the B1 phylogroup and most isolates with more than one virulence gene, other than fim $\mathrm{H}$, belonged to this group. Isolates belonging to the $\mathrm{A}$ phylogroup were most frequently isolated from TW samples, and isolates belonging to the B2 and D phylogroups usually related to extraintestinal pathogenic strains, were less frequently isolated (Figure 2). However, isolates belonging to the B2 group exhibited higher pathogenic potential, as revealed by the presence of virulence markers (Table 2). Three isolates from each TW and FS samples belonged to the D phylogroup; all of them displayed only the fim $\mathrm{H}$ gene, except for one FS isolate, which also had the kps gene. 


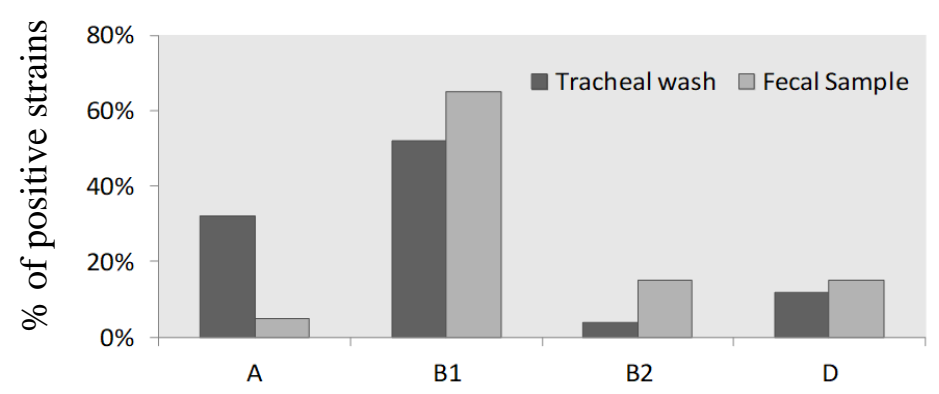

Figure 2. Phylogenetic groups of $E$. coli isolated from mule foals.

Paired samples from TW and FS ( $\mathrm{n}=8$ for each, total 16) E. coli isolates and 5 TW Klebsiella pneumoniae isolates and two unpaired $K$. pneumoniae FS isolates with representative antimicrobial resistance and virulence profiles were used for the RAPD assay.

RAPD analysis of the E. coli isolates using the 1254 oligonucleotide generated 19 polymorphic bands, ranging in size between 200 to $2,000 \mathrm{bp}$, while in K. pneumoniae, 17 bands were observed which also ranged between 200 to 2,000 bp in size. Amplification profiles of two E. coli and one $K$. pneumoniae isolate could not be obtained with the primer used.

Eight RAPD-PCR types (named I to VIII) and 14 subtypes (named in lowercase) were identified among the E. coli isolates. All isolates from TW samples belonged to types IV to VII, while most isolates of fecal origin belonged to types I, II, III and VIII. Isolates belonging to the B2 phylogroup, which displayed several virulence genes, regardless of their origin (TW or FS), showed distinct RAPD types (Figure 3).

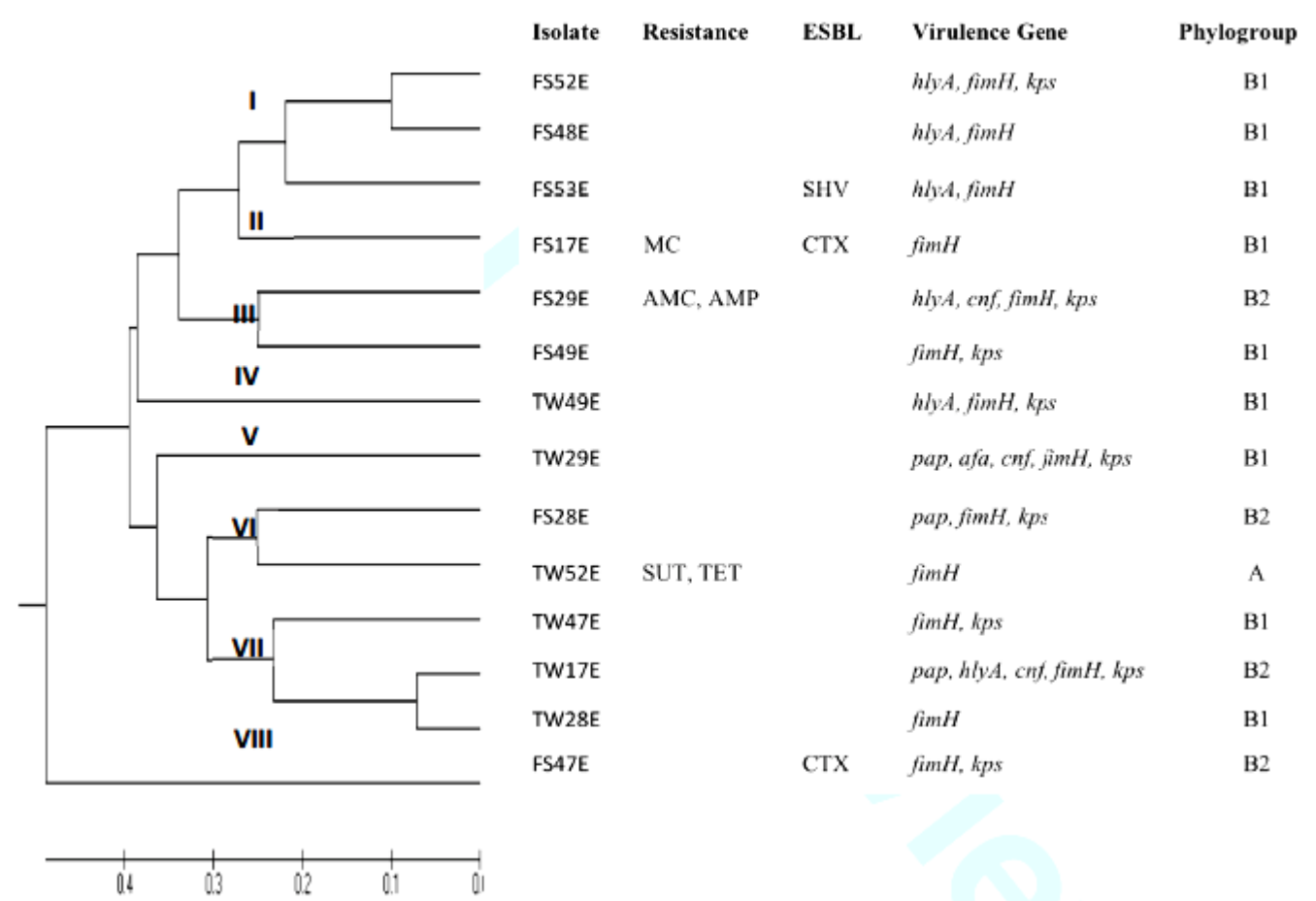

Figure 3. Dendrogram of E. coli isolates from tracheal washes (TW) and fecal samples (FS) constructed by the MEGA4 software using the UPGMA method after RAPD-PCR assays with the 1254 primer. The scale values denote the genetic distance between the branches. 
We found a significant diversity between the strains of respiratory and fecal origin with the use of the 1254 primer and a $75 \%$ similarity criterion for a RAPD types. These results suggest that the bacterial strains found in TW and FS had different sources, and it is possible that the respiratory tract strains were passed on to the foals from the adult animals. Nevertheless, further studies are necessary to confirm this possibility.

The dendrogram generated for the $K$. pneumoniae isolates grouped the isolates under five RAPD types. The two isolates of the type I showed some similarities with respect to resistance profile, ESBL-encoding genes and virulence profile while isolates of types IV and V showed identical resistance profiles and ESBLencoding genes (Figure 4).

From the clinical point of view, the detection of bacterial strains having virulence markers in both $\mathrm{H}$ and $\mathrm{S}$ animals should be treated as normal and expected since these microorganisms behave generally as opportunistic agents, depending largely on the host defense to cause a pathological condition. Moreover, the same reasoning can be applied to the similar occurrence of resistant strains from $\mathrm{H}$ and $\mathrm{S}$ animals. However, the combination of these characteristics with molecular epidemiological markers such as phylogroups and RAPD profiles pointed to a possible distinct origin of such strains.

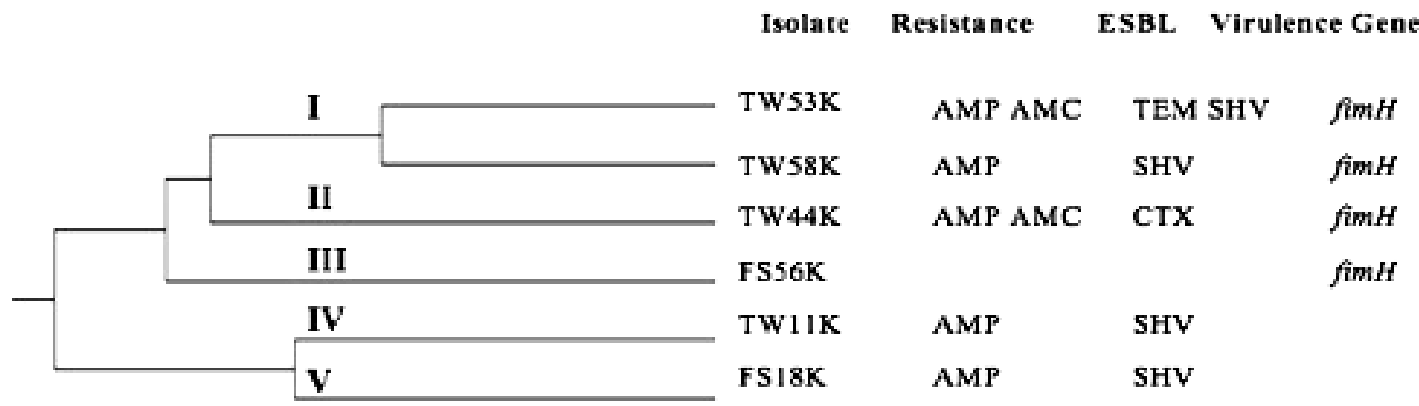

\begin{tabular}{llll}
1 & 1 & 1 & 1 \\
\hline 0 & 03 & 02 & 01
\end{tabular}

Figure 4. Dendogram of Klebsiella pneumoniae isolates obtained from tracheal washed (TW) and fecal samples (FS) of mule foals; constructed by UPGMA method after RAPD-PCR assays using the primer 1254. The scale values denotge the genetic distance between the branches.

\section{CONCLUSION}

To the best of our knowledge, this is the first report on the characterization of Escherichia coli and Klebsiella sp. isolated from mule foals less than six months of age. The predominance of both these bacterial species in TW samples enabled characterization of these strains and the results showed that they are genetically diverse. Some of them are multiresistant to antibiotics, produce ESBL, and carry extraintestinal virulence genes. A better understanding of bacteria involved in colonization or respiratory tract disease of mule foals can guide the adoption of more effective management practices and treatment strategies.

\section{REFERENCES}

ARMSTRONG, J.; GIBBS, A.; PEAKALL, R.; WEILLER, G. RAPDistance program version 1.03 for the analysis of patterns of RAPD fragments. Camberra: Australian National University, 1994.

BÉLANGER, L.; GARENAUX, A.; HAREL, J. et al. Escherichia coli from animal reservoirs as a potential source of human extraintestinal pathogenic E. coli. FEMS Immunol. Med. Microbiol., v.62, p.1-10, 2011.

CHAMPS, C.; RICH, C.; CHANDEZON, P. et al. Factors associated with antimicrobial resistance among clinical isolates of Klebsiella pneumoniae: 1-Year survey in a French university hospital. Eur. J. Clin. Microbiol. Infect. Dis., v.23, p.456-462, 2004. 
CLARK, C.; GREENWOOD, S.; BOISON, J.O. et al. Bacterial isolates from equine infections in western Canada (1998-2003). Can. Vet. J., v.49, p.153-160, 2008.

CLERMONT, O.; BONACORSI, S.; BINGEN, E. Rapid and simple determination of the Escherichia coli phylogenetic group. Appl. Environ. Microbiol., v.66, p.4555-4558, 2000.

CLSI, 2008. Performance standards for antimicrobial disk and dilution susceptibility tests for bacteria isolated from animals. 3.ed. M31-A3 document. Wayne: CLSI, 2008.

CLSI, 2012, Performance standards for antimicrobial susceptibility testing; twentysecond informational supplement. M100-S22 document. Wayne: CLSI, 2012.

COHEN, N.D. Causes of and farm management factors associated with disease and death in foals. J. Am. Vet. Med. Assoc., v.204, p.1644-1651, 1994.

DEB ROY, C.; ROBERTS, E.; JAYARAO, B.M.; BROOKS, J.W. Bronchopneumonia associated with extraintestinal pathogenic Escherichia coli in a horse. J. Vet. Diagn. Invest., v.20, p.661-664, 2008.

DOLEJSKA, M.; DUSKOVA, E.; RYBARIKOVA, J. et al. Plasmids carrying bla CTX-M-1 and $q n r$ genes in Escherichia coli isolates from an equine clinic and a horseback riding centre. $J$. Antimicrob. Chemother., v.66, p.757-764, 2011.

EL FERTAS-AISSANI, R.; MESSAI, Y.; ALOUACHE, S.; BAKOUR, R. Virulence profiles and antibiotic susceptibility patterns of Klebsiella pneumoniae strains isolated from different clinical specimens. Pathol. Biol., v.61, p.209-16, 2013.

JOHNSON, J.R.; STELL, A.L.; SCHEUTZ, F. et al. Analysis of the $\mathrm{F}$ antigen-specific papA alleles of extraintestinal pathogenic Escherichia coli using a novel multiplex PCR-based assay. Infect. Immun., v.68, p.1587-1599, 2000.

JOHNSON, J.R.; VAN DER SCHEE, C.; KUSKOWSKI, M.A. et al. Phylogenetic background and virulence profiles of fluoroquinolone-resistant clinical Escherichia coli isolates from the Netherlands. J. Infect. Dis., v.186, p.1852-1856, 2002.
JONES, C.; TUCKMAN, M.; KEENEY, D. et al. Characterization and sequence analysis of extended-spectrum- $\beta$ lactamase-encoding genes from Escherichia coli, Klebsiella pneumoniae, and Proteus mirabilis isolates collected during tigecycline phase 3 clinical trials. Antimicrob. Agents Chemother., v.53, p.465-475, 2009.

LÉGUILLETTE R.; ROY, M. F.; LAVOIE, J.P. Foal Pneumonia. In: LEKEUX, P. (Ed.). Equine respiratory diseases. Ithaca: International Veterinary Information Service, 2002. Available in: <http://www.ivis.org/special_books/Lekeux/ toc.asp>. Accessed in: 7 Mar, 2016.

MADDOX, T.W.; CLEGG, P.D.; DIGGLE, P.J. et al. Cross-sectional study of antimicrobialresistant bacteria in horses. Part 1: Prevalence of antimicrobial-resistant Escherichia coli and methicillin-resistant Staphylococcus aureus. Equine Vet. J., v.44, 289-296. 2012

MARKEY, B.; LEONARD, F.; ARCHAMBAUT, M. et al. Clinical veterinary microbiology. 2.ed. [Dublin]: Mosby Elsevier, 2013. 920p.

MAYNARD, C.; BEKAL, S.; SANSCHAGRIN, F. et al. Heterogeneity among virulence and antimicrobial resistance gene profiles of extraintestinal Escherichia coli isolates of animal and human origin. J. Clin. Microbiol., v.42, p.5444-5452, 2004

MELLOR, D.J.; STAFFORD, K.J. Animal welfare implications of neonatal mortality and morbidity in farm animals. Vet. J., v.168, p.118133, 2004.

PACHECO, A.B.F.; GUTH, B.E.C.; SOARES, K.C.C. et al. Random amplification of polymorphic DNA reveals serotype- specific clonal clusters among enterotoxigenic Escherichia coli strains isolated from humans. $J$. Clin. Microbiol., v.35, p.1521-1525, 1997.

PUSTERLA， N.; WATSON, J.L.; WILSON, W.D. Diagnostic approach to infectious respiratory disorders. Clin. Tech. Equine Pract., v.5, p.174-186, 2006.

RIBAS, L.D.M.; MORAES, C.M.; LINS, L.A. et al. Fatores de risco associados a doenças respiratórias em potros Puro Sangue Inglês do nascimento ao sexto mês de vida. Ciênc. Rural, v.39, p.1789-1794, 2009. 
RUSSELL, C.M.; AXON, J.E.; BLISHEN, A.; BEGG, A.P. Blood culture isolates and antimicrobial sensitivities from 427 critically ill neonatal foals. Aust. Vet. J., v.86, p.266-271, 2008.

RYU, S.H.; KOO, H.C.; LEE, Y.W. et al. Etiologic and epidemiologic analysis of bacterial infectious upper respiratory disease in thoroughbred horses at the Seoul Race Park. $J$. Vet. Sci., v.12, p.195-198, 2011.

SCHOSTER, A.; STAEMPFLI, H.R.; ARROYO, L.G. et al. Longitudinal study of Clostridium difficile and antimicrobial susceptibility of Escherichia coli in healthy horses in a community setting. Vet. Microbiol., v.159, p.364-370, 2012.

SZMOLKA, A.; NAGY, B. Multidrug resistant commensal Escherichia coli in animals and its impact for public health. Front. Microbiol., v.4, p.258-270, 2013.

TAMURA, K.; DUDLEY, J.; NEI, M.; KUMAR, S. Mega4: molecular evolutionary genetics analysis (MEGA) software version 4.0. Mol. Biol. Evol., v.24, p.1596-1599, 2007.
THEELEN, M.J.P.; WILSON, W.D.; EDMAN, J.M. et al. Temporal trends in prevalence of bacteria isolated from foals with sepsis: 19792010. Equine Vet. J. v.46, p.169-173, 2014.

THIEMANN, A.K. Respiratory disease in the donkey. Equine Vet. Educ., v.24, p.69-478, 2012.

USEIN, C.R.; DAMIAN, M.; TATU-CHITOIU, D. et al. Prevalence of virulence genes in Escherichia coli strains isolated from Romanian adult urinary tract infection cases. J. Cell. Mol. Med., v.5, p.303-10, 2001.

WIEGAND, I.; GEISS, H. K.; MACK, D. et al. Detection of extended-spectrum beta-lactamases among Enterobacteriaceae by use of semiautomated microbiology systems and manual detection procedures. J. Clin. Microbiol., v.45, p.1167-1174, 2007. 